\title{
Embryonic stem cell-derived cystic embryoid bodies form vascular channels: an in vitro model of blood vessel development
}

\author{
RONG WANG, REBECCA CLARK and VICTORIA L. BAUTCH* \\ Department of Biology, University of North Carolina at Chapel Hill, Chapel Hill, North Carolina 27599, USA \\ *Author for correspondence
}

\section{Summary}

Murine embryonic stem cells can differentiate in vitro to form cystic embryoid bodies (CEB) that contain different structures and cell types. The blood islands are one such structure that consist of immature hematopoietic cells surrounded by endothelial cells, the first identifiable vascular cells. CEBs differentiated in vitro developed blood islands initially, and subsequently these blood islands matured to form vascular channels containing hematopoietic cells. Phase contrast microscopy demonstrated the presence of channels in mature CEBs grown in suspension culture, and high resolution light and electron microscopy showed that the cells lining these channels were endothelial cells. The channels appeared less organized than the vasculature of the mature yolk sac. The hematopoietic cells were occasionally seen 'flowing' through the CEB channels, although their numbers were reduced relative to the yolk sac. Analysis of primary CEB cultures showed the presence of cells with two characteristics of endothelial cells: approximately $30 \%$ of the cells labelled with fluorescent acetylated low density lipoprotein and a small number of cells were positive for von Willebrand's factor by immunostaining. Thus we conclude that a primitive vasculature forms in CEBs differentiated in vitro, and that not only primary differentiation of endothelial cells but also some aspects of vascular maturation are intrinsic to this cell culture system. CEBs are therefore a useful model for the study of developmental blood vessel formation.

Key words: vascular development, endothelial cell, murine ES cells, in vitro differentiation.

\section{Introduction}

Blood vessel formation is a complex process that results in the elaboration of a vasculature with a distinct pattern (reviews Wagner, 1980; Noden, 1991). Blood vessels are one of the first organ systems to develop during embryogenesis, and the vasculature continues to develop and expand into the postnatal period (Stewart and Wiley, 1981; Bar, 1983; Coffin and Poole, 1988; Pardanaud et al., 1989). A key control point in blood vessel formation is the response of the endothelial cell to developmental signals, and this response has two components. Vascular development by in situ primary differentiation of endothelial cells from an undifferentiated precursor cell is called vasculogenesis, whereas the subsequent "sprouting" and organization of endothelial cells into blood vessels is called angiogenesis (Houser et al., 1961; Risau and Lemmon, 1988). Angiogenesis involves endothelial cell migration, division, and the establishment of junctional connections. Although both processes have been elegantly described (Sabin, 1917; Haar and Ackerman, 1971; Ausprunk and Folkman, 1977), the molecular controls that underlie developmental blood vessel formation are largely unknown.

Vasculogenesis occurs when a putative precursor cell differentiates to form an angioblast and a stem cell for the hematopoietic lineages (Sabin, 1920; Noden, 1991). The angioblast gives rise to endothelial cells. Evidence from quail-chick graft experiments suggests that vasculogenesis in the avian embryo is restricted both temporally and spatially to the extraembryonic yolk sac, the aortic and cardinal vein condensations of the embryo proper, and some organ rudiments (Reagan, 1915; Coffin and Poole, 1988; Pardanaud et al., 1989). In contrast, the kidney and brain are vascularized by sprouts of endothelial cells that invade the rudiment (Stewart and Wiley, 1981; Ekblom et al., 1982; Bar, 1983). In the yolk sac, blood islands develop from mesodermal cell clumps called angioblastic cords that are found between the mesodermal and endodermal cell layers. The blood island precursors differentiate to form clusters of immature hematopoietic cells surrounded by endothelial cells (Houser et al., 1961; Gonzalez-Crussi, 1971; Haar and Ackerman, 1971). The blood island endothelial cells then migrate, divide, 
and establish connections that form the yolk sac vasculature. The vitelline vein and artery develop within the embryo and connect the embryonic vasculature to the yolk sac vasculature.

Studies of vasculogenesis and early angiogenesis in the avian embryo have been aided by an endothelial cell marker that is expressed early in development, $\mathrm{MB}$-1or QH-1 (Peault et al., 1983; Pardanaud et al., 1987). The development of the vasculature in the mammalian embryo seems to parallel that of the avian embryo, but studies have been hampered by both the inaccessibility of the mammalian embryo and the lack of a marker for early endothelial cells in the mammal (Auerbach et al., 1985; Gumkowski et al., 1987; Zetter, 1988). Recent advances in the ability to manipulate genetic information in the mouse have made dissection of molecular processes that control development feasible in this system (review, Robertson, 1986). For example, the generation of null mutations by homologous recombination in embryonic stem (ES) cells in culture with subsequent reintroduction to the animal has revealed roles for specific growth factors, proto-oncogenes, homeobox genes, and transcription factors in developmental processes (DeChiara et al., 1990; Thomas and Capecchi, 1990; Koller et al., 1990; McMahon and Bradley, 1990; Zijlstra et al., 1990; Soriano et al., 1991; Chisaka and Capecchi, 1991; Mucenski et al., 1991; Pevny et al., 1991; Joyner et al., 1991; Schwartzberg et al., 1991; Tybulewicz et al., 1991). Moreover, the ability of ES cells to differentiate into multiple cell types in vitro has been investigated, and a reproducible pattern of differentiation in suspension culture results in the formation of a structure called a cystic embryoid body (CEB). The cystic portion of the CEB is similar to the visceral yolk sac of the mouse embryo, and CEBs often contain clusters of hematopoietic cells that resemble blood islands (Doetschman et al., 1985; Risau et al., 1988).

We have investigated in vitro differentiation of ES cells to form blood island-containing CEBs as a model for the study of embryonic blood vessel formation. We found that the blood islands of CEBs are lined by endothelial cells. Moreover, we observed that the blood islands of the embryoid bodies in suspension culture mature to form connections and channels that resemble blood vessels. Thus signals for both the primary differentiation of endothelial cells from pluripotent stem cells and for some of the cellular processes involved in subsequent vascular development are intrinsic to the ES cell culture system.

\section{Materials and methods}

\section{Culture of $C E B$}

ES cell line $1 E G / 2$ was a kind gift of Drs. R. M. Schmitt and $H$. R. Snodgrass (Schmitt et al., 1991). ES cell line E14TG2a was a kind gift of Dr. M. Hooper (Hooper et al., 1987). The ES cell lines were maintained in the undifferentiated state as described by Schmitt et al. (1991) with conditioned medium from 5637 human bladder carcinoma cells as a source of LIF/DIA (leukemia inhibitory factor/differentiation inhibit- ing activity) (Williams et al., 1988b). The differentiation of ES cells to CEBs was carried out as described (Schmitt et al., 1991), except that $20 \%$ human cord serum was replaced by selected lots of $20 \%$ fetal bovine serum. Briefly, undifferentiated ES cells were cultured for 4-9 days without further feeding. The cells were removed in clumps with dispase (Boehringer Mannheim), and the clumps were transferred to plastic Petri dishes and cultured in suspension with medium containing $20 \%$ fetal bovine serum, $150 \mu \mathrm{M} \alpha$-thioglycerol, 50 $\mu \mathrm{g} / \mathrm{ml}$ of gentamicin in Dulbecco's modified Eagle medium (DMEM). The CEBs were routinely visualized with an Olympus CK2 inverted microscope with phase contrast optics, and larger CEBs were chosen for counting purposes. Cells that were round, refractile, and not tightly attached to each other were considered to be hematopoietic cells. The presence of cavities or channels lined by a thin layer of cells in CEBs was counted positive for channels. The CEBs that exhibited general or localized rhythmic contraction were counted positive for beating. The CEBs with hematopoietic cells moving inside the channels were counted positive for flowing. The CEBs were also visualized with a Zeiss IM 35 microscope fitted with Nomarski Differential Interference Contrast (DIC) optics for better resolution of channel borders.

\section{Benzidine staining}

Erythroblasts in CEBs were stained for hemoglobin as described (O'Brien, 1960). Briefly, about 10 CEBs were washed with PBS (phosphate buffered saline), then incubated in a freshly made staining solution containing $87 \mathrm{mg} / \mathrm{ml} \mathrm{o}$ dianisidine (Sigma), $23 \mathrm{mM}$ sodium acetate buffer ( $\mathrm{pH} 4.7$ ), $0.9 \% \mathrm{H}_{2} \mathrm{O}_{2}, 61.22 \%$ ethanol at R.T. for $15 \mathrm{~min}$. Samples were dehydrated through ethanol and mounted.

\section{Semi-thin section and electron microscopy}

The semi-thin and ultra-thin sections were made according to standard procedure. Briefly, mouse yolk sac or CEBs were fixed in Karnovsky's fixative ( $2 \%$ glutaraldehyde- $2 \%$ paraformaldehyde) buffered in $0.1 \mathrm{M}$ sodium cacodylate for $1 \mathrm{hr}$ at R.T., postfixed in $1 \%$ osmium tetroxide in the same buffer, dehydrated and embedded in Araldite-502. Semi-thin sections ( $1 \mu \mathrm{m}$ thickness) were stained with toluidine blue. Ultra-thin sections were cut at $70 \mathrm{~nm}$, stained in $4 \%$ aqueous uranyl acetate and $0.5 \%$ lead citrate, and observed with a Zeiss $10 \mathrm{~A}$ Transmission Electron Microscope at a voltage of $80 \mathrm{kV}$.

\section{Primary culture}

CEBs with channels were washed in PBS, cut with fine scissors and treated with a solution containing $0.1 \%$ trypsin and $0.04 \%$ EDTA for $10 \mathrm{~min}$ at $37^{\circ} \mathrm{C}$. The reaction was stopped by adding medium containing serum and the trypsinEDTA was removed by centrifugation. The cells were cultured in the same medium used for $\mathrm{CEB}$ culture at $37^{\circ} \mathrm{C}$, $10 \% \mathrm{CO}_{2}$, on tissue culture plates coated with $1.5 \%$ gelatin. The primary cultures were cultured for 12 days before labelling with DiI-Ac-LDL (acetylated low density lipoprotein labelled with $1,1^{\prime}$-dioctadecyl-1-3,3,3',3',-tetramethylindocarbocyanine perchlorate) or staining for the presence of vWF (von Willebrand's factor). The expanded cultures were maintained in culture 8-12 weeks with 4-5 passages.

\section{DiI-Ac-LDL labelling}

Primary cultures and expanded cultures were labelled with DiI-Ac-LDL as described (Dubois et al., 1991) with modifications. The cells were incubated with the medium plus 5 $\mu \mathrm{g} / \mathrm{ml}$ Dil-Ac-LDL (Biomedical Technologies Inc.) for 4 hours at $37^{\circ} \mathrm{C}$. After labelling the cells were washed for $15 \mathrm{~min}$ 


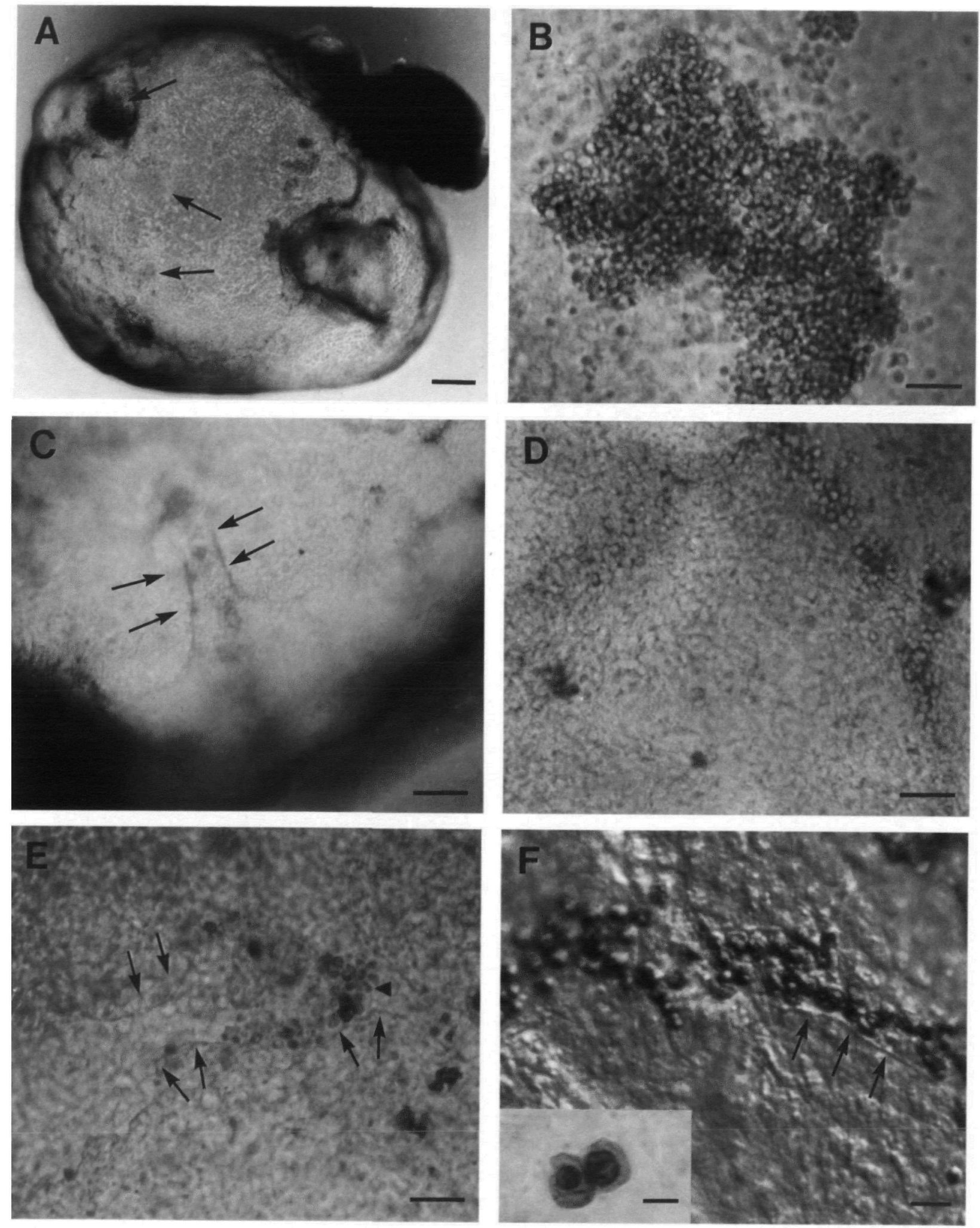

Fig. 1. Channel formation in CEBs. CEBs were generated as described in Methods, and they were visualized with phase contrast microscopy (A-E) or stained with benzidine, dehydrated and mounted, and visualized with DIC optics (F). (A) An 11 day CEB. The arrows point to several blood islands, and the dark area in the upper right is a non-cystic clump of tissue which often developed in conjunction with the cystic portions of the CEB. Scale bar $200 \mu \mathrm{m}$. (B) A higher magnification of one of the blood islands in a day $22 \mathrm{CEB}$. Note the cluster of orange-red hematopoietic cells. Scale bar $50 \mu \mathrm{m}$. (C) A 17 day CEB. The arrows point to a channel on the surface, and the hematopoietic cells within the channel are clearly visible. Scale bar $100 \mu \mathrm{m}$. (D) A higher magnifcation of distribution of hematopoietic cells in a 17 day CEB. Although the boundaries of the channel are not visible, the nonrandom distribution of hematopoietic cells suggests that they are within a channel. Scale bar $50 \mu \mathrm{m}$. (E) Channel of a 24 day CEB. The arrows point to some of the channel boundaries, and the arrowhead points to hematopoietic cells within the channel. Scale bar $50 \mu \mathrm{m}$. (F) An 18 day CEB stained with benzidine, showing a channel boundary (arrows) surrounding the red-brown stained hematopoietic cells. Scale bar $20 \mu \mathrm{m}$. Inset: light micrograph of hematopoietic cells in a CEB stained with benzidine. Note that these cells are nucleated. Scale bar $10 \mu \mathrm{m}$. 
at $37^{\circ} \mathrm{C}$ with medium without DiI-Ac-LDL, followed by 3 rinses in PBS. They were fixed for $10 \mathrm{~min}$ in $10 \%$ formalin (Tissue-Fixx, Lerner Laboratories, PA), and stored in PBS. Fluorescence was visualized with a Nikon Diaphot microscope with standard rhodamine filters.

\section{$v W F$ staining}

The primary cultures and expanded cultures were stained for vWF as described (Dubois et al., 1991) with slight modifications. Briefly, the cells were grown on gelatin coated plates and fixed $5 \mathrm{~min}$ in cold methanol. Endogenous peroxidase activity was inhibited by treatment with $0.75 \%(\mathrm{v} / \mathrm{v}) \mathrm{H}_{2} \mathrm{O}_{2}$ in PBS for $10 \mathrm{~min}$. The cells were blocked for $2 \mathrm{hr}$ in a solution of $10 \%(\mathrm{v} / \mathrm{v})$ horse serum, $1 \%(\mathrm{w} / \mathrm{v})$ bovine serum albumin, 50 mM HEPES (4-[2-hydroxyethyl]-1-piperazine ethanesulfonic acid) ( $\mathrm{pH} \mathrm{7.2)} \mathrm{in} \mathrm{DMEM,} \mathrm{incubated} \mathrm{with} \mathrm{rabbit} \mathrm{anti-human}$ vWF antiserum (Dakopatts, CA) at 1:100 for $1 \mathrm{hr}$, then incubated with goat anti-rabbit HRP (horseradish peroxidase) at 1:500 for $30 \mathrm{~min}$. All antibodies were diluted in blocking solution without bovine serum albumin. The samples were incubated in a solution of $0.25 \mathrm{mg} / \mathrm{ml} \mathrm{3}^{\prime}, 3^{\prime}$ diaminobenzidine, $3 \mathrm{mg} / \mathrm{ml}$ nickel sulfate, and $0.003 \% \mathrm{H}_{2} \mathrm{O}_{2}$ in PBS for $10 \mathrm{~min}$, and rinsed in PBS.

\section{Results}

\section{Channel formation in cystic embryoid bodies}

We investigated the potential of in vitro differentiation of ES cells for studies of blood vessel formation. Undifferentiated ES cells were grown in the presence of LIF/DIA conditioned medium and passed every 2-3 days. Cultures to undergo in vitro differentiation were precultured for 4-9 days without media change or passage. When large, rounded colonies with differentiated cells at the edges were observed, the cultures were removed with dispase and cultured in suspension (Schmitt et al., 1991). The day of dispase treatment was considered to be day 0 of differentiation ( 0 day). The cells formed embryoid bodies that progressed through several stages as documented by Doetschmen et al. (1985), including formation of cystic structures, beating structures, and blood islands. Approximately $60 \%$ of the embryoid bodies formed cystic structures.

Careful observation of CEBs at 8-20 days revealed channels within the wall of the cystic structure, and blood cells were found in these channels rather than in circumscribed blood islands (Fig. 1). CEBs were found with multiple areas of hematopoietic cell concentration (Fig. 1A). Some of the hematopoietic cells were found in clumps as they usually are in blood islands (Fig. 1B). However, some of the hematopoietic cells were more dispersed within channels (Figs 1C and D). The channel walls were thin, and in the absence of hematopoietic cells it was difficult to distinguish the boundaries of the channels (Fig. 1E). The hematopoietic cells appeared to lose their heavy pigmentation with hemoglobin as differentiation progressed, and at late stages (20-25 days) careful observation was required to identify the lightly pigmented round hematopoietic cells in the channels (Fig. 1E). The erythroblasts, however, were unambiguously identified by staining with benzidine, and benzidine positive cells were found within the channels (Fig. 1F). As previously described (Doetschman et al., 1985), all blood cells were nucleated as are mouse yolk sac erythrocytes.

The presence of channels in the CEBs was further demonstrated by observation with Differential Interference Contrast (DIC) optics. Fig. 2A shows two areas of hematopoietic cell concentration that are joined by a channel. It is likely that this structure was once two independent blood islands that formed a connecting channel. The boundaries of the channels were more clearly delineated using DIC optics than with phase contrast microscopy (compare Fig. $1 \mathrm{E}$ and $2 \mathrm{~B}$ ). The channels seemed to emanate from blood islands (Fig. 2A), but they appeared more cavernous than normal blood vessels. These observations revealed a lack of overall organization or pattern to the channels.

Occasionally the hematopoietic cells within the channels were observed to flow. Fig. 2C shows a channel containing several groups of hematopoietic cells, and the same field several minutes later had a different distribution of hematopoietic cells within the channel (Fig. 2D). The cells that are missing were observed to "flow" from left to right in the channel. This cell movement was exclusively seen in cystic structures that had beating areas.

To quantitate the phenomenon of channel formation relative to other differentiation parameters, ES cells obtained from two different sources and at different passage numbers were allowed to differentiate in vitro. At 10-15 days, the well-formed CEBs were examined by phase microscopy for hematopoietic cells, channels, beating areas, and "flow" of blood cells (Table 1). The results showed that both cell lines were capable of forming CEBs with blood cells and channels, and both cell lines made CEBs that exhibited beating and flow of hematopoietic cells in channels. A significant proportion of CEBs ( $46 \%-77 \%$ ) formed blood cells and/or channels, and the ranges of both parameters overlapped with both cell lines. A few CEBs with channels had no visibly detectable blood cells, and several CEBs with blood cells had no detectable channels (data not shown).

Only unambiguously positive CEBs were scored for each parameter, and both hematopoietic cells and channels can be difficult to detect in whole CEBs viewed by phase contrast microscopy, so the numbers were possibly an underestimate of the occurrence of blood cells or channels. To determine if hematopoietic cells were underestimated, we stained a random group of CEBs with benzidine, mounted them on microscope slides, and scored each $\mathrm{CEB}$ for benzidine positive cells. We found that $81.7 \%(58 / 71)$ of the CEBs contained benzidine positive cells (data not shown). Fewer CEBs with blood cells were scored by phase contrast microscopy $(63 \%, 77 \%)$. It is likely, therefore, that the percentage of CEBs with hematopoietic cells was slightly underestimated by visualization with phase contrast microscopy.

A lower percentage of CEBs had detectable areas of beating $(18 \%, 47 \%)$ than had hematopoietic cells, and a small percentage of CEBs had areas of "flow" where 

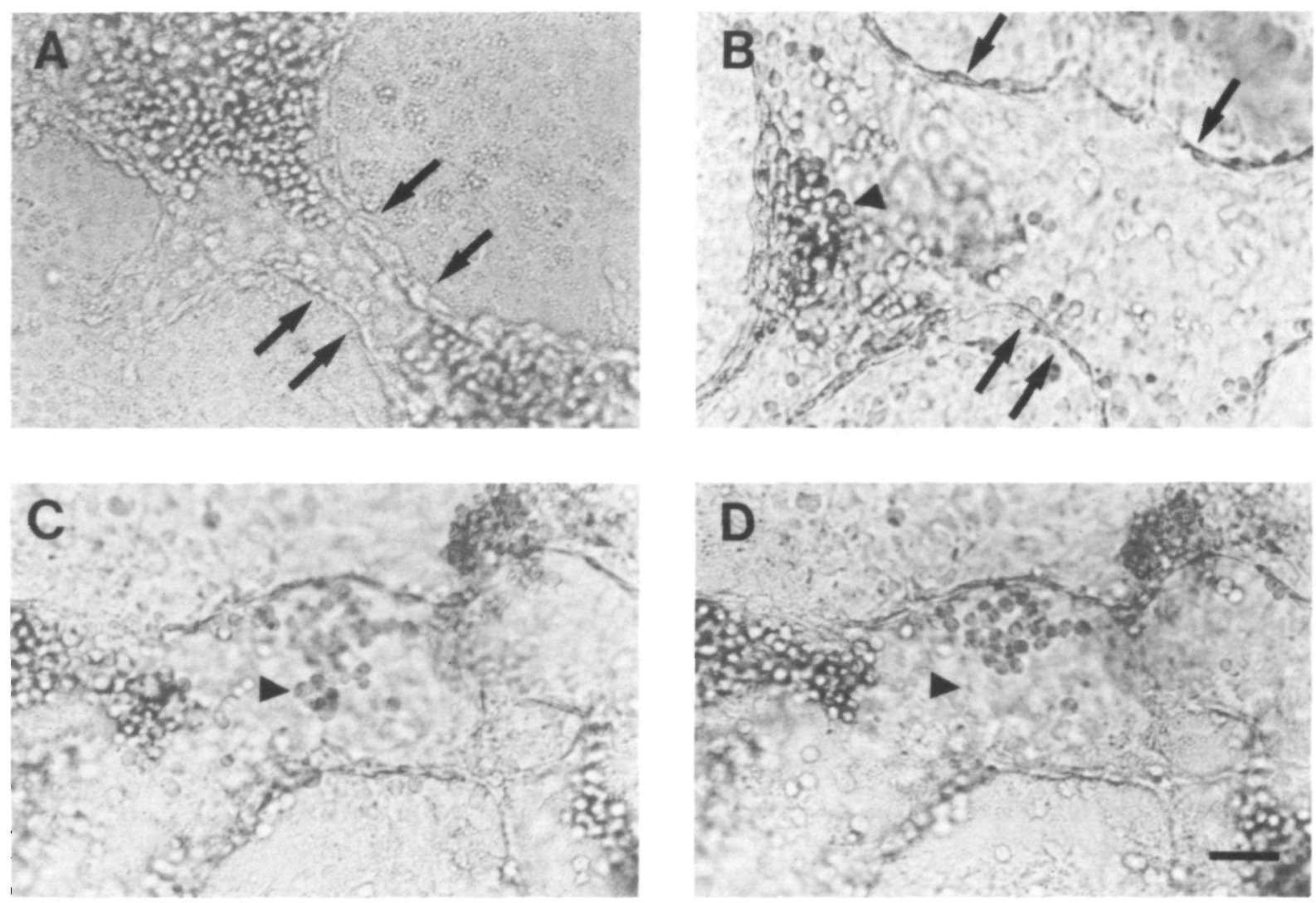

Fig. 2. DIC visualization of CEB channels and hematopoietic cell movement. CEBs are at day 19 of differentiation and were photographed in culture media using DIC optics. (A) Two blood islands (upper left and lower right) that are joined by a channel. The arrows point to channel boundaries, and the refractile cells within the blood islands are hematopoietic cells. (B) The widened area of a channel. Arrows point to boundaries, and the arrowhead points to hematopoietic cells within the structure. (C) Channel showing the presence of hematopoietic cells in several areas. Note the hematopoietic cells pointed to by the arrowhead. (D) The same channel as in $C$ approximately 5 min. later. The arrowhead points to the same position, showing that some of the hematopoietic cells have moved. Scale bar $50 \mu \mathrm{m}$.

Table 1. Differentiation parameters of cystic embryoid bodies

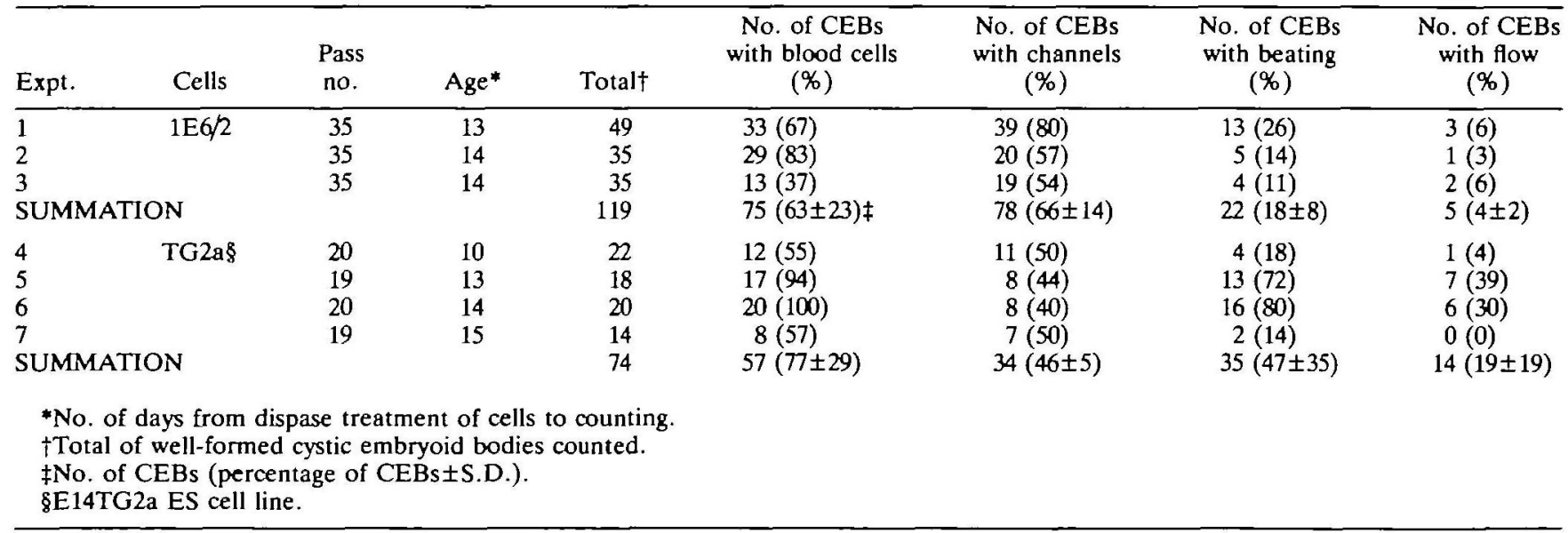

blood cells were moving ( $4 \%, 19 \%$ ) (Table 1$)$. There were some differences in the percentage of CEBs with each parameter of differentiation between cell lines, but the passage number also varied so the reason for these differences is not known. We did not evaluate any potential trends among experiments because two different observers scored different experiments, but within the age of CEBs scored (10-15 days) channels were observed at all ages.

To determine the kinetics of these differentiation parameters, groups of CEBs were examined with phase contrast microscopy between days 8-20 (Table 2 and 
Table 2. Time course of cystic embryoid body maturation

\begin{tabular}{|c|c|c|c|c|c|c|c|c|c|c|}
\hline$\frac{\text { Age* }}{8}$ & $\frac{\text { Expt. }}{1}$ & $\frac{\text { Total } t}{275}$ & \multicolumn{2}{|c|}{$\begin{array}{c}\text { No. of CEBs } \\
\text { with blood cells } \\
(\%)\end{array}$} & \multicolumn{2}{|c|}{$\begin{array}{l}\text { No. of CEBs } \\
\text { with channels } \\
(\%)\end{array}$} & \multicolumn{2}{|c|}{$\begin{array}{c}\text { No. of CEBs } \\
\text { with beating } \\
(\%)\end{array}$} & \multicolumn{2}{|c|}{$\begin{array}{c}\text { No. of CEBs } \\
\text { with flowing } \\
(\%)\end{array}$} \\
\hline 8 & $\begin{array}{l}1 \\
2 \\
3\end{array}$ & $\begin{array}{r}275 \\
68 \\
158\end{array}$ & $\begin{array}{r}212 \\
15 \\
93\end{array}$ & $\begin{array}{l}(77) \\
(22) \\
(59)\end{array}$ & $\begin{array}{r}231 \\
38 \\
106\end{array}$ & $\begin{array}{l}(84) \\
(56) \\
(67)\end{array}$ & $\begin{array}{l}27 \\
22 \\
21\end{array}$ & $\begin{array}{l}(10) \\
(32) \\
(13)\end{array}$ & $\begin{array}{l}0 \\
0 \\
1\end{array}$ & $\begin{array}{l}(0) \\
(0) \\
(1)\end{array}$ \\
\hline 10 & $\begin{array}{l}1 \\
2 \\
3\end{array}$ & $\begin{array}{l}98 \\
36 \\
50\end{array}$ & $\begin{array}{l}76 \\
17 \\
34\end{array}$ & $\begin{array}{l}(71) \\
(47) \\
(68)\end{array}$ & $\begin{array}{l}77 \\
17 \\
42\end{array}$ & $\begin{array}{l}(71) \\
(47) \\
(84)\end{array}$ & $\begin{array}{l}29 \\
27 \\
29\end{array}$ & $\begin{array}{l}(30) \\
(77) \\
(58)\end{array}$ & $\begin{array}{l}3 \\
3 \\
2\end{array}$ & $\begin{array}{l}(3) \\
(8) \\
(4)\end{array}$ \\
\hline 12 & $\begin{array}{l}1 \\
2 \\
3\end{array}$ & $\begin{array}{l}242 \\
102 \\
140\end{array}$ & $\begin{array}{r}181 \\
55 \\
88\end{array}$ & $\begin{array}{l}(75) \\
(54) \\
(63)\end{array}$ & $\begin{array}{r}186 \\
48 \\
65\end{array}$ & $\begin{array}{l}(77) \\
(47) \\
(46)\end{array}$ & $\begin{array}{r}129 \\
88 \\
108\end{array}$ & $\begin{array}{l}(53) \\
(86) \\
(77)\end{array}$ & $\begin{array}{r}7 \\
14 \\
21\end{array}$ & $\begin{array}{r}(3) \\
(14) \\
(15)\end{array}$ \\
\hline 16 & $\begin{array}{l}1 \\
2 \\
3\end{array}$ & $\begin{array}{r}234 \\
96 \\
106\end{array}$ & $\begin{array}{r}140 \\
41 \\
60\end{array}$ & $\begin{array}{l}(60) \\
(43) \\
(57)\end{array}$ & $\begin{array}{r}134 \\
28 \\
48\end{array}$ & $\begin{array}{l}(57) \\
(29) \\
(45)\end{array}$ & $\begin{array}{r}121 \\
73 \\
64\end{array}$ & $\begin{array}{l}(52) \\
(76) \\
(60)\end{array}$ & $\begin{array}{r}13 \\
14 \\
9\end{array}$ & $\begin{array}{r}(6) \\
(15) \\
(8)\end{array}$ \\
\hline 20 & $\begin{array}{l}1 \\
2 \\
3\end{array}$ & $\begin{array}{l}164 \\
104 \\
100\end{array}$ & $\begin{array}{l}64 \\
31 \\
28\end{array}$ & $\begin{array}{l}(39) \\
(30) \\
(28)\end{array}$ & $\begin{array}{l}55 \\
38 \\
31\end{array}$ & $\begin{array}{l}(34) \\
(37) \\
(31)\end{array}$ & $\begin{array}{l}56 \\
45 \\
43\end{array}$ & $\begin{array}{l}(34) \\
(43) \\
(43)\end{array}$ & $\begin{array}{l}3 \\
4 \\
0\end{array}$ & $\begin{array}{l}(2) \\
(4) \\
(0)\end{array}$ \\
\hline
\end{tabular}

Fig. 3). All CEBs were formed from $1 E 6 / 2$ ES cells, and the results of two or three different observers were pooled for each time point. Comparison of three different time courses showed quantitative variations in the percentage of CEBs exhibiting a differentiation parameter among the time courses. For example, the percentage of CEBs with channels at day 10 was $47 \%$ for time course 2 and $84 \%$ for time course 3 (Table 2 and Fig. 3B).

The shape of the graph for each parameter, however, was remarkably consistent among the time courses. For example, in all time courses the percentage of CEBs with blood cells peaked between days 8-12 (Table 2 and Fig. 3A). Likewise, the percentage of CEBs with channels peaked at 8-10 days, while the percentage of CEBs that exhibited beating peaked at 12 days in all cases and declined thereafter (Table 2 and Fig. 3B-C). The apparent decline in the percentage of CEBs with blood cells and channels at later times could have resulted from loss or disintegration of these cells or structures, or the decline may have been artifactual due to the increasing difficulty in viewing with phase contrast microscopy as the CEBs age.

To obtain a more accurate assessment of the percentage of blood cells at each time point, a number of the CEBs were stained with the erythroblast marker benzidine and examined by light microscopy (Table 3 and Fig. 3E). The results showed that the percentage of CEBs with benzidine positive cells peaked at days 8-12, and remained high for the duration of the time course. The peak of the benzidine curve corresponds to the peak of the blood cell curve, but the maximums and shapes of the curves differ. Thus, as noted for the initial characterization, the percentage of benzidine positive CEBs at peak is $90 \%-100 \%$, whereas the percentage of CEBs with blood cells at peak is $50 \%-80 \%$. Moreover, while the blood cell percentage as scored by visualization declines to $30 \%-40 \%$ by day 20 , the benzidine positive percentage remains high at $90 \%-100 \%$, indicating that erythroblasts survive to day 20 of differentiation.

\section{Morphological evaluation of CEB channels}

To determine if endothelial cells were involved in channel formation in the CEBs, we examined sections of the CEBs by light and electron microscopy. Light microscopic analysis showed that the cystic portion of a $\mathrm{CEB}$ at 8 days resembled the extraembryonic yolk sac of an 8.5 day mouse embryo (Fig. 4A-B, D-E). Both had a thick outer layer of endoderm, and multiple blood islands were found between the endoderm and an inner

Table 3. Time course of benzidine staining of cystic embryoid bodies

\begin{tabular}{|c|c|c|c|c|}
\hline Age* & Expt. & Total $\dagger$ & $\begin{array}{c}\text { No. of CEBs } \\
\text { benzidine+ }\end{array}$ & $\begin{array}{l}\% \text { of } \mathrm{CEBs} \\
\text { benzidinet }\end{array}$ \\
\hline 1 & $\begin{array}{l}1 \\
2 \\
3\end{array}$ & $\begin{array}{r}147 \\
108 \\
90\end{array}$ & $\begin{array}{l}3 \\
1 \\
4\end{array}$ & $\begin{array}{l}2 \\
1 \\
4\end{array}$ \\
\hline 4 & $\begin{array}{l}1 \\
2 \\
3\end{array}$ & $\begin{array}{r}107 \\
90 \\
83\end{array}$ & $\begin{array}{r}48 \\
6 \\
13\end{array}$ & $\begin{array}{r}45 \\
7 \\
16\end{array}$ \\
\hline 8 & $\begin{array}{l}1 \\
2 \\
3\end{array}$ & $\begin{array}{r}20 \\
6 \\
11\end{array}$ & $\begin{array}{r}19 \\
3 \\
6\end{array}$ & $\begin{array}{l}95 \\
50 \\
55\end{array}$ \\
\hline 12 & $\begin{array}{l}1 \\
2 \\
3\end{array}$ & $\begin{array}{l}19 \\
11 \\
11\end{array}$ & $\begin{array}{l}19 \\
10 \\
11\end{array}$ & $\begin{array}{r}100 \\
91 \\
100\end{array}$ \\
\hline 16 & $\begin{array}{l}1 \\
2 \\
3\end{array}$ & $\begin{array}{l}11 \\
10 \\
13\end{array}$ & $\begin{array}{r}9 \\
9 \\
13\end{array}$ & $\begin{array}{r}82 \\
90 \\
100\end{array}$ \\
\hline 20 & $\begin{array}{l}1 \\
2 \\
3\end{array}$ & $\begin{array}{l}16 \\
14 \\
18\end{array}$ & $\begin{array}{l}14 \\
13 \\
18\end{array}$ & $\begin{array}{r}88 \\
93 \\
100\end{array}$ \\
\hline
\end{tabular}

* No. of days from dispase treatment of cells to assay. tTotal of embryoid bodies assayed at each time point. 

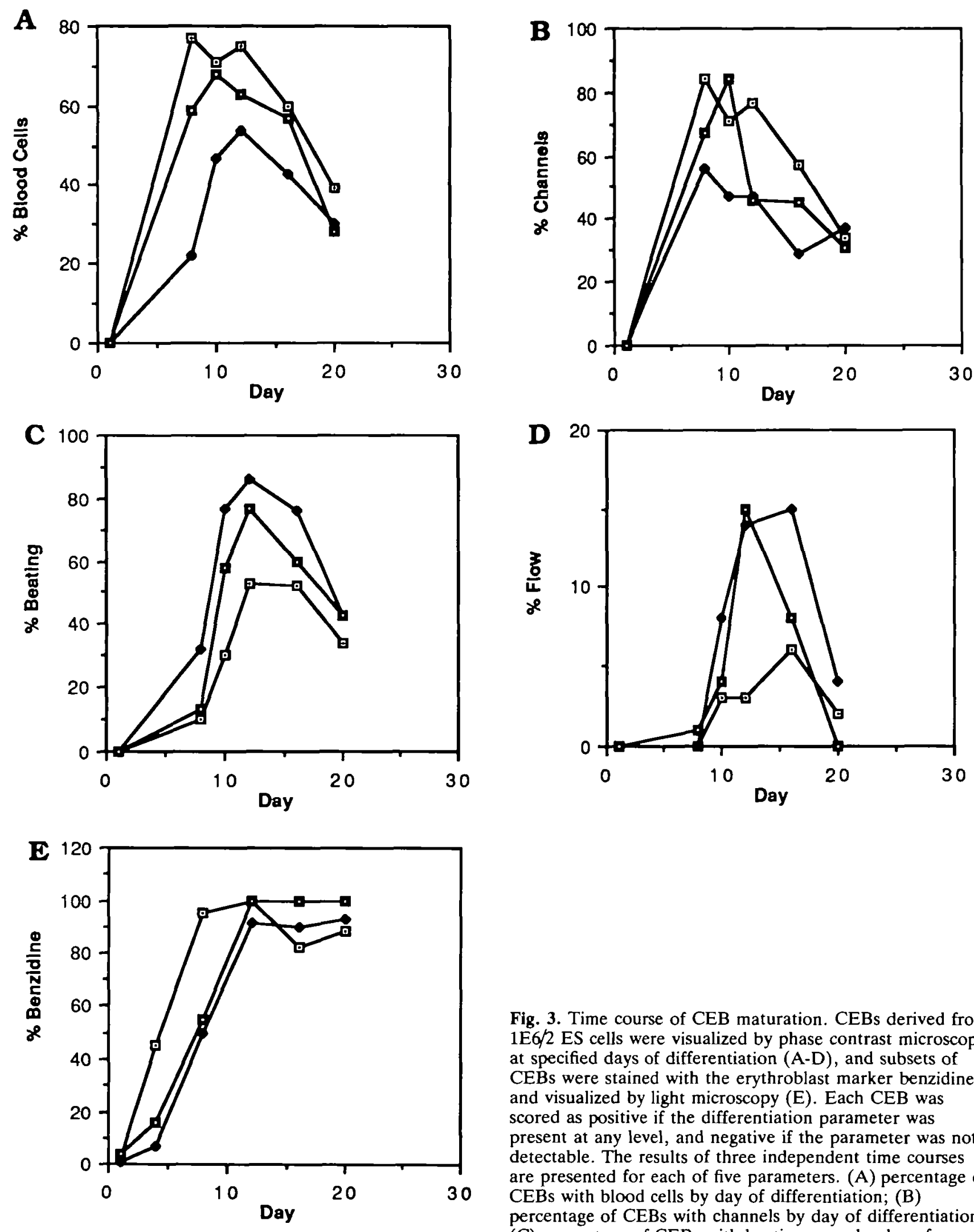

Fig. 3. Time course of CEB maturation. CEBs derived from $1 \mathrm{E} 6 / 2$ ES cells were visualized by phase contrast microscopy at specified days of differentiation (A-D), and subsets of CEBs were stained with the erythroblast marker benzidine and visualized by light microscopy (E). Each CEB was scored as positive if the differentiation parameter was present at any level, and negative if the parameter was not detectable. The results of three independent time courses are presented for each of five parameters. (A) percentage of CEBs with blood cells by day of differentiation; (B) percentage of CEBs with channels by day of differentiation; (C) percentage of CEBs with beating areas by day of differentiation; (D) percentage of CEBs with flow of hematopoietic cells by day of differentiation; (E) percentage of CEBs with benzidine positive cells by day of differentiation. 
mesothelial cell layer. The blood islands in both cases were lined with a single cell layer of thin elongated cells that resembled endothelial cells (Fig. 4D-E). Fewer blood cells were present in the CEB blood islands compared to the yolk sac blood islands, and the whole structure of the CEB blood island was slightly more disorganized than the yolk sac blood island (compare Fig. 4D and E).

Examination of an older CEB (23 days) showed some similarities to the younger embryo yolk sac and $\mathrm{CEB}$ such as the presence of an endodermal layer, mesothelial cell layer, and lumina lined with endothelial-like cells (Fig. 4C,F-G). There were differences in the older $\mathrm{CEB}$, however, that included a thickening of the structure with more cells and extracellular material between the endoderm and mesothelial cells. These changes are also found in yolk sac blood islands at later stages (Morris et al., 1991, data not shown). The endodermal layer was more flattened in the older CEB, and the lumina of the channels contained fewer blood cells.

Electron microscopic analysis showed that the CEB channels were lined with cells morphologically identical to endothelial cells (Fig. 5). Comparison of the relative positions of cells in the embryonic yolk sac blood island with the CEB blood island (Fig. 5A and B) showed in both cases an endodermal layer, endothelial cell layer, hematopoietic cells within a lumen, endothelial cell layer, and mesothelial cell layer, progressing from outside to inside. The cells lining the blood island lumen were identified as endothelial cells on the basis of their morphological characteristics. They are thin elongated cells with slightly bulging nuclei found as a single cell layer (Gonzalez-Crussi, 1971; Haar and Ackerman, 1971). In contrast, the endodermal cells are large polar cells with microvilli on the outer surfaces, the hematopoietic cells are rounded unattached cells with a high nuclear/cytoplasmic ratio, and mesothelial cells are more rounded. In addition, the cells lining the lumina of both structures connect by junctions that are typical of the connections made by endothelial cells (Fig. 5D and $E)$. As noted above, the organization of the cells in the CEB blood island appeared slightly disorganized relative to the embryonic structure, and at the EM level some hematopoietic cells were slightly atypical, with cellular pieces and small cells in the lumen of the CEB blood island (Fig. 5B).

Examination of the channels of an older CEB (23 days) showed that these structures exhibited both smilarities and differences with the earlier blood islands (Fig. 5C). The cells lining the channel are endothelial cells by previously described morphological criteria. The lumina of the channels contained occasional blood cells (see Fig. 4F,G). The material surrounding the channels and endothelial cells appeared less cellular, and the distinct cell types described above were only identified at much lower magnifications (data not shown). Some of the extracellular material resembled collagen fibers, and the endothelial cells were joined by typical junctions (Fig. 5F). Thus by morphological criteria the cells lining the blood islands of CEBs and the derivative channels are endothelial cells.

\section{Marker analysis}

We assayed embryo yolk sacs and CEBs for cells that had endothelial cell markers by labelling with DiI-AcLDL and staining for vWF immunohistochemically. Yolk sacs or CEBs were dissociated into single cells and clumps of cells, allowed to attach to tissue culture dishes, and incubated under conditions that favor expansion of endothelial cells. The cells were assayed either as primary cultures (without passage) at 12 days after plating, or the CEBs were assayed as expanded cultures (with 4-5 passages).

All cultures were a mixed population of cells that labelled with DiI-Ac-LDL and cells that did not take up the labelled compound with great affinity (Fig. 6). Primary cultures of embryo yolk sac or CEBs had fluorescent cells isolated or in small clumps (Fig. 6A, $C)$, and these cells were more prevalent and dispersed in the expanded cultures (Fig. 6E, G). The percentage of fluorescent cells in each culture was estimated at $35 \%$ in embryo yolk sac primary culture, $30 \%$ in CEB primary culture, and $75 \%$ in CEB expanded culture (data not shown). The labelled cells had a punctate pattern of flourescence that is characteristic of endothelial cells, and when they were found in close proximity to one another they never showed overlap of cell boundaries (Fig. 6A, C, E, G). Macrophages also take up the DiI-Ac-LDL marker, but they are resistant to trypsinization and therefore unlikely to be passed into the expanded culture (Freshney, 1987).

Cell cultures prepared in the same way were subjected to immunohistochemical staining with vWF, another endothelial cell marker that is found in most endothelial cells and in megakaryocytes (Fig. 7). vWFstained cells were seen in all cultures, although they represented a small proportion of the cells in the expanded CEB cultures and an even smaller proportion of the cells in both embryo yolk sac and CEB primary cultures. In situ immunohistology of embryo yolk sac blood islands and CEB blood islands demonstrated only rare $\mathrm{vWF}$ positive cells although numerous embryonic blood vessels were stained (R.C. and V.L.B., unpublished results). These results are consistent with the interpretation that the early endothelial cells in the mouse embryonic yolk sac and in the CEBs are for the most part negative for $\mathrm{VWF}$ by immunohistochemical staining.

\section{Discussion}

Pluripotent murine ES cells can undergo a programmed differentiation in vitro to form CEBs (Doetschman et al., 1985; Risau et al., 1988). We have presented evidence that both primary differentiation of endothelial cells and vascular maturation occur reproducibly in CEBs differentiated in suspension culture, leading to the development of a primitive vasculature in these in vitro structures. Channels containing hematopoietic 

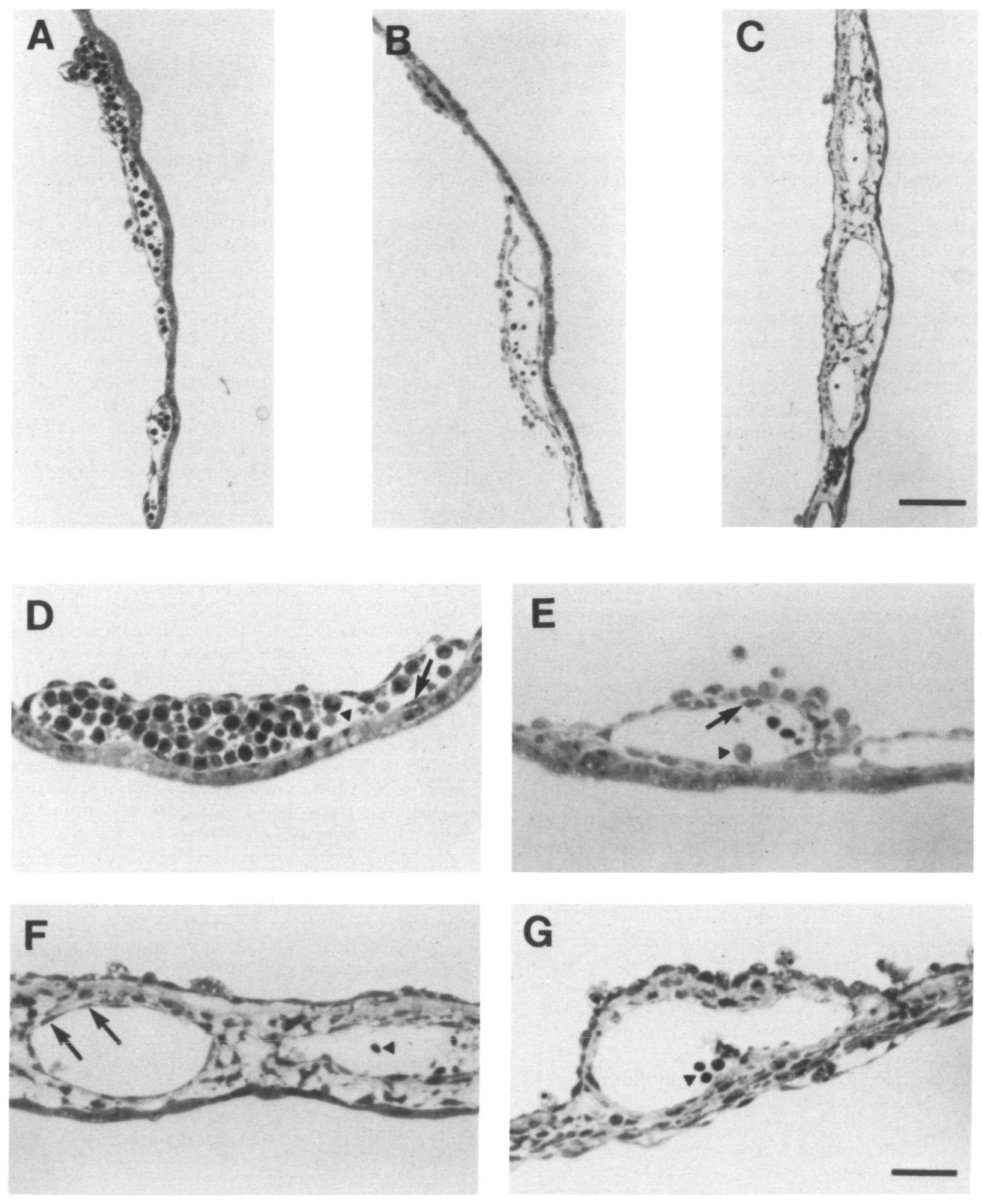

cells were visualized in the CEBs. These channels have a thin wall that consists of a single layer of endothelial cells as defined by morphological criteria. Cells positive for two endothelial cell markers, DiI-Ac-LDL uptake and $v W F$ staining, were found in primary cultures of CEBs or mouse embryonic yolk sac.

Blood island formation has been described in CEBs and the developmental progression of hematopoietic cells has been documented with molecular markers (Doetschman et al., 1985; Risau et al., 1988; Lindenbaum and Grosveld, 1990; Schmitt et al., 1991; Wiles and Keller, 1991; Burkert et al., 1991). The presence of 
Fig. 4. Light microscopy of embryonic yolk sac, CEB blood islands, and CEB channels. Samples were fixed in paraformaldehyde/glutaraldehyde, embedded in araldite502 , sectioned and stained with toluidine blue. A-C, Lumen of yolk sac or CEB to the left, scale bar $100 \mu \mathrm{m}$. $D-G$, Lumen of yolk sac or CEB at the top, scale bar 50 $\mu \mathrm{m}$. (A) Yolk sac of day 8.5 embryo (day of plug $=0.5$ day). The yolk sac endoderm is at the right, and the relative positions of several blood islands are shown. The inner lining of the yolk sac consists of mesothelial cells. (B) An 8 day CEB. This structure resembles the yolk sac of $A$ with the endoderm at the right, and blood islands between the endoderm and mesothelium. Note the scarcity of hematopoietic cells in the blood islands. (C) A 23 day CEB. This structure contains a flattened endodermal layer at the right, and more cellular and extracellular material between the endoderm and the mesothelium. The blood islands contain very few hematopoietic cells. (D) Blood island in yolk sac of a day 8.5 embryo. Arrow points to a presumptive endothelial cell that lines the blood island, and arrowhead points to hematopoietic cell. (E) Blood island of an 8 day CEB. Arrow points to a presumptive endothelial cell that lines the blood island, and arrowhead points to a hematopoietic cell. (F) Blood island of a 23 day CEB. Arrows point to presumptive endothelial cells and arrowhead points to a rare hematopoietic cell within the blood island. (G) Another blood island of a 23 day CEB. Arrowhead points to rare hematopoietic cells.

endothelial cells in these structures, however, has been inferred by analogy to the blood islands of the yolk sac. Using high resolution light and electron microscopy, we have shown that the cells lining the blood islands in CEBs are indistinguishable from endothelial cells. They are found in a single cell layer of thin elongated cells with bulging nuclei connected by tight junctions. Cells with this morphology are seen lining all vascular structures, including the yolk sac blood islands of the mouse (Haar and Ackerman, 1971; this report) and avian embryos (Houser et al., 1961; Gonzalez-Crussi, 1971).

The endothelial cells surrounding the blood islands were subsequently found to line interconnected channels in the CEBs. These channels are most likely a maturation of the blood islands to form a primitive vasculature. The presence of these structures in CEBs cultured in suspension indicates that several components of the program of vascular differentiation are intrinsic to the ES cell culture system. Doetschman and colleagues documented further development of the blood islands only when the CEBs developed in the peritoneum of a mouse or were placed on a chick chorioallantoic membrane (Risau et al., 1988). Although different cell lines or different culture conditions may account for the discrepancy, two different ES cell lines derived from mice of different genetic backgrounds developed into CEBs with channels in our studies. A more likely possibility is that channel formation in CEBs is a general phenomenon that is difficult to visualize. The hematopoietic cells of the CEB become less readily detectable as the CEBs mature, and thus the normal definition of the vasculature by these cells is lost.

The reason for the obscuring of hematopoietic cells as CEBs mature is not known. As the vascular channels develop the total volume of space available to the erythroblasts may increase faster than the expansion of this cell population. An alternative intriguing possibility is that the developmental program for hematopoietic cells and blood vessels becomes dissociated in terms of requirements, and in older CEBs hematopoietic cells may cease to expand or even decline while the endothelial cells continue their developmental progression to form a vasculature. Several lines of evidence are consistent with the latter hypothesis. Our electron microscopic analysis and benzidine marker analysis revealed fewer and more atypical hematopoietic cells in CEBs than in the yolk sac blood islands. The amount of globin RNA in synchronized CEBs declines dramatically at later stages (Lindenbaum and Grosveld, 1990; Wiles and Keller, 1991). Chimeric or mutant embryos that do not develop a hematopoietic system do not exhibit overt vascular disruption (Mucenski et al., 1991; Pevny et al., 1991), and those that sustain vascular disruption seem to develop hematopoietic cells (Williams et al., 1988a). Finally, the dissociation of vascular and hematopoietic development is also indicated by the observation that the endoderm is required for the formation of the endothelium but not for erythropoiesis in organ cultures of the chick yolk sac (Wilt, 1965; Miura and Wilt, 1969). The accessibility of the murine CEB system should permit determination of the effects of specific factors on both hematopoiesis and vascular development.

We have begun a search for markers of early murine endothelial cells. Although we have not yet identified a marker that reliably stains early endothelial cells in situ, cells in primary cultures of CEBs take up labelled AcLDL with the kinetics of endothelial cells (Voyta et al., 1984; Yablonka-Reuveni, 1989). Macrophages also take up Ac-LDL avidly, but the labelled cells are not likely to be macrophages because cells with macrophage markers are not detectable or are found in small numbers in CEBs (Doetschman et al., 1985; Schmitt et al., 1991; Wiles and Keller, 1991).

Another marker that is found in most but not all mature endothelial cells is vWF (review, Zetter, 1988). Only a small percentage of the cells in primary culture stain for this marker. Although it may be that the vWF positive cells are the only endothelial cells in the cultures, it is rather likely that most murine yolk sac endothelial cells do not express this marker at detectable levels at the stages analyzed. Evidence for the latter interpretation is that the same small percentage of vWF positive cells was found in primary embryo cultures, and we detected only rare vWF staining of the vascular lining of yolk sac blood islands and in CEBs (R. C. and V.L.B., unpublished results). Moreover, both the proportion of Dil-Ac-LDL positive cells and the proportion of $\mathrm{VWF}$ positive cells increased in expanded cultures of CEB cells, suggesting that a group of cells that is DiI-Ac-LDL positive has a small subset of 

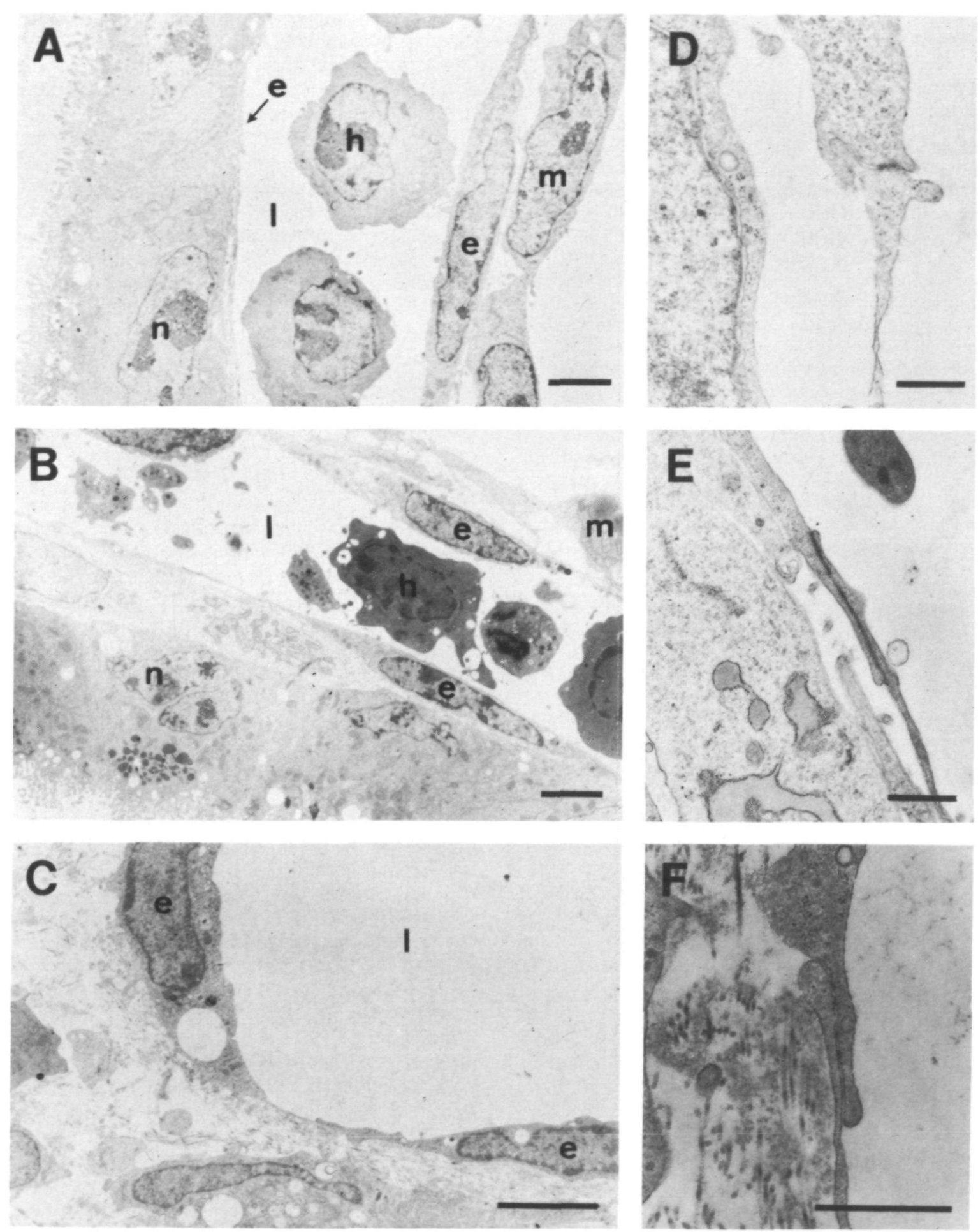

Fig. 5. Electron microscopy of embryonic yolk sac, CEB blood islands, and CEB channels. Samples were fixed and prepared for transmission EM as described in Methods. (A) Blood island of an 8.5-day embryo yolk sac. From left to right are visceral endoderm, a thin lining of endothelial cell cytoplasm, hematopoietic cells in the blood island lumen, endothelial cells, mesothelial cells, and the yolk sac lumen (exocoelom). (B) Blood island of a day 8 CEB. From lower left to upper right are endoderm cells, a cell of uncertain identity, endothelial cell, hematopoietic cells in the blood island lumen, endothelial cell, mesothelial cell, and CEB lumen. (C) Channel of a 23 day CEB. The blood island lumen is surrounded by endothelial cells. (D) Endothelial cell tight junction in blood island of day 8.5 embryo yolk sac.

(E) Endothelial cell tight junction in blood island of day $8 \mathrm{CEB}$. (F) Endothelial cell tight junction in channel of a day 23 CEB. Abbreviations: $n$, endoderm cell; e, endothelial cell; $h$, hematopoietic cell; 1 , lumen of blood island; m, mesothelial cell. Scale bar A-C, $5 \mu \mathrm{m} ; \mathrm{D}-\mathrm{F}, 1 \mu \mathrm{m}$. 

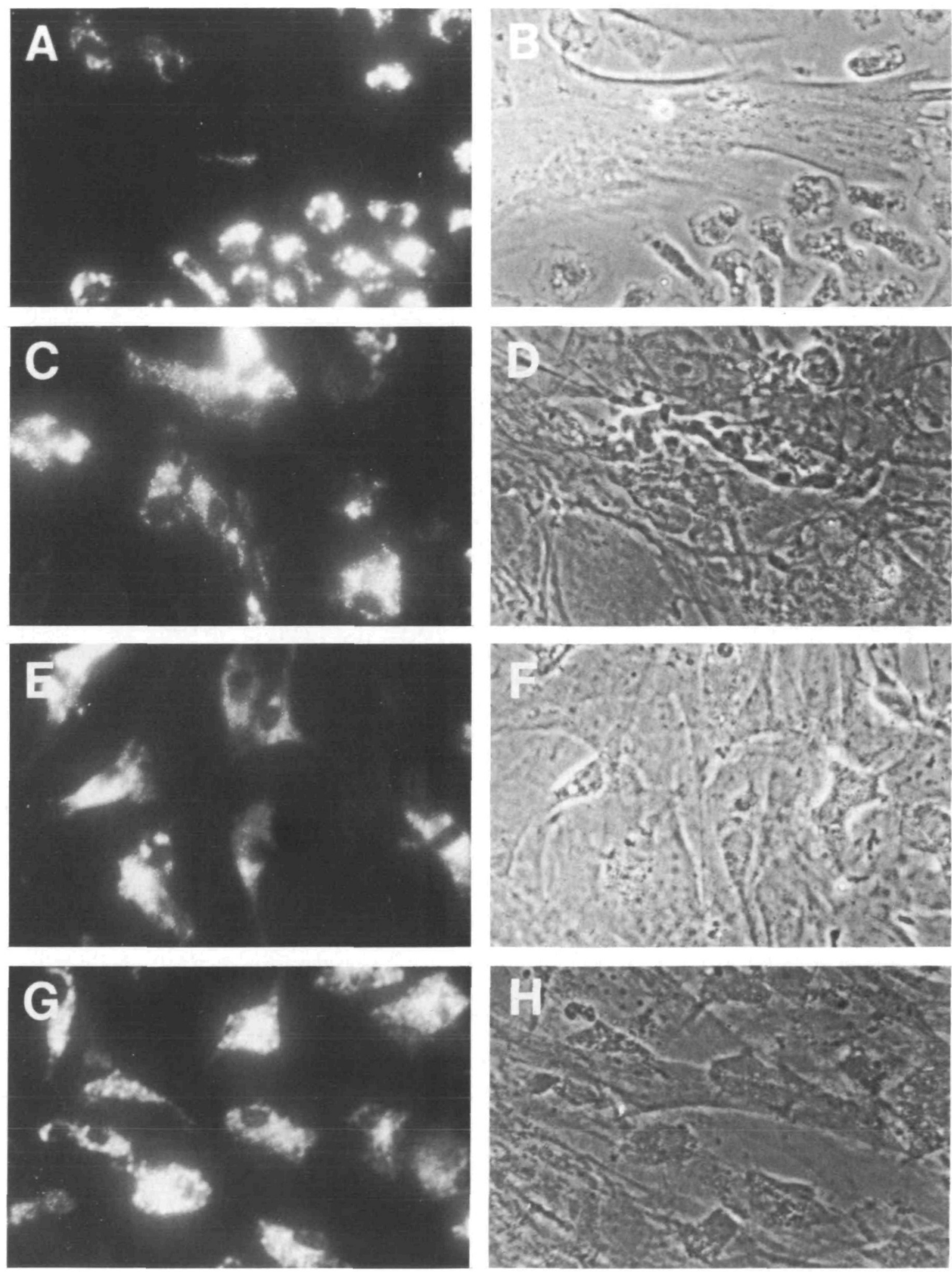

Fig. 6. DiI-Ac-LDL labelling of primary embryonic and CEB cultures. Embryonic yolk sacs or CEBs were dissociated and plated onto gelatin-coated plates. Cells were either labelled as primary cultures (A-D), or after expansion by $2-4$ passages (E-H). A, C, E, G, fluorescence microscopy; B, D, F, H, phase contrast microscopy. (A-B) labelled cells of day 10 embryonic yolk sac cultures at 12 days after plating; (C-D) labelled cells of day 12 CEBs at 12 days after plating. (E-F) labelled cells of day $14 \mathrm{CEBs}$ at the 5th passage. (G-H) labelled cells of day 20 CEBs at the 4 th passage. Magnification $100 \times$. 

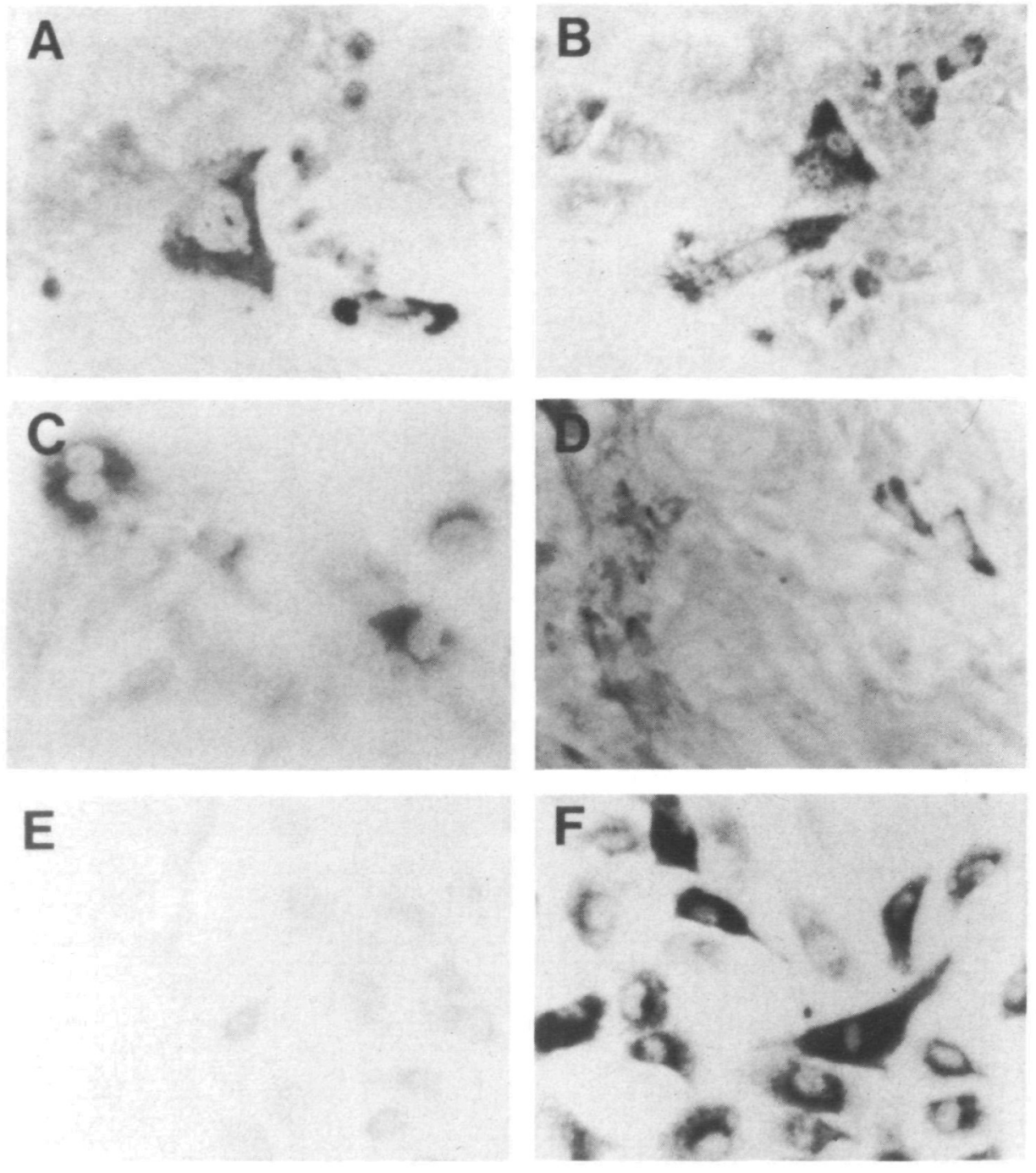

Fig. 7. Immunohistochemical staining for von Willebrand's factor (vWF) in embryo and CEB cultures. Cells were dissociated and plated onto gelatin-coated plates. Cells were either incubated with anti-vWF antiserum as primary cultures (A-B), or after expansion for 4-5 passages (C,D). Visualization of HRP labelled goat anti-rabbit secondary antibody was with diaminobenzidine. (A) Cells of day 10 embryonic yolk sac cultured for 12 days prior to staining; (B) Cells of day 12 CEB cultured for 12 days prior to staining; (C) Cells of day 14 CEB stained at the 5th passage; (D) Cells of day 20 CEB stained at the 4th passage; (E) NIH 3 T3 cells; (F) Bovine aortic endothelial cells (BAEC). Magnification $100 \times$.
vWF positive cells. The only cells known to express both DiI-Ac-LDL and vWF are endothelial cells (Zetter, 1988; Dubois et al., 1991). This hypothesis is also consistent with the finding that some groups of embryonic murine endothelial cells remain vWF negative during development (R.C. and V.L.B., unpublished results).

The primitive vasculature that developed in the CEBs was less organized than the yolk sac vasculature, and in place of a patterned system there were channels of varying sizes connecting cavernous areas. Thus, while both primary endothelial cell differentiation and further vascular maturation are intrinsic to the ES cell culture system, the signals for overall pattern are lacking. This suggests that vascular pattern is not predetermined, but that it results from intercellular communication between endothelial cells and cells that are not present in CEBs. This observation is supported by transplant experiments showing that graft cells develop the vascular pattern of the graft site rather than that of the site of origin (Noden, 1991). Some candidates for cells that may influence vascular pattern are ectodermal derivatives such as neural crest, or other mesodermally derived components of the mature vasculature such as pericytes or smooth muscle cells. Further vascular maturation may also be influenced by hydrostatic pressure (Wagner, 1980).

These observations, taken together, show that the in vitro differentiation of murine ES cells to form CEBs includes a program for vascular development with both primary endothelial cell differentiation and subsequent maturation to form vascular channels. Culture of CEBs in suspension is sufficient to reproducibly elaborate this program, but the signals required for an ordered pattern of blood vessels appear to be missing. The manipulability of this system at the genetic level should permit determination of the function of individual gene products in blood vessel formation. For example, a number of angiogenic factors have been identified by bioassay, but their roles in developmental processes are not known (reviews, Folkman and Klagsbrun, 1987; Klagsbrun and D'Amore, 1991). The genes encoding these factors can theoretically be eliminated by homologous recombination in undifferentiated ES cells (Mortensen et al., 1991; Cruz et al., 1991), and the resulting phenotype can be scored in the differentiation assay. 
The accessibility of the in vitro system also provides a way to manipulate vascular development temporally, via the addition of neutralizing antibodies or anti-sense nucleic acids corresponding to relevant molecules. Thus elucidation of the molecular mechanisms of developmental blood vessel formation should be possible using ES cell-derived CEBs.

We are grateful to R. Schmitt and H. R. Snodgrass for ES cells and for patient help with ES cell techniques. We thank M. Hooper for ES cells, Z. Chen for technical assistance, V. Madden for help with electron microscopy, K. McCarthy for the use of a fluorescence microscope, $\mathrm{S}$. Whitfield for artwork and photography, and K. Mohr, L. Scott, T. Futch, T. Friday, and $\mathrm{L}$. Harding for lab help. We thank our colleagues $\mathrm{T}$. Doetschman, D. Coffin, N. Maeda, and J. McNeish and lab colleagues N. Dubois, A. Helseth, and A. Jonczyk for helpful discussions, and B. Popko for critical reading of the manuscript. This work was supported by a grant from the NIH (HL43174) to V.L.B

\section{References}

Auerbach, R., Alby, L., Morrissey, L. W., Tu, M. and Joseph, J. (1985). Expression of organ-specific antigens on capillary endothelial cells. Microvasc. Res. 29, 401-411.

Ausprunk, D. H. and Folkman, J. (1977). Migration and proliferation of endothelial cells in preformed and newly formed blood vessels during tumor angiogenesis. Microvasc. Res. 14, 53-65.

Bar, T. (1983). Patterns of vascularization in the developing cerebral cortex. In Development of the vascular system, pp. 20-36. Ciba Foundation Symp. 100. London: Pitman Books.

Burkert, U., von Ruden, T. and Wagner, E. F. (1991). Early fetal hematopoietic development from in vitro differentiated embryonic stem cells. The New Biologist 3, 698-708.

Chisaka, O. and Capecchi, M. R. (1991). Regionally restricted developmental defects resulting from targeted disruption of the mouse homeobox gene hox-1.5. Nature 350, 473-479.

Coffin, J. D. and Poole, T. J. (1988). Embryonic vasculature development: immunohistochemical identification of the origin and subsequent morphogenesis of the major vessel primordia in quail embryos. Development 102, 735-748.

Cruz, A., Coburn, C. M. and Beverley, S. M. (1991). Double targeted gene replacement for creating null mutants. Proc. natn. Acad. Sci. U.S.A. 88, 7170-7174.

DeChiara, T. M., Efstratiadis, A. and Robertson, E. J. (1990). A growth-deficiency phenotype in heterozygous mice carrying an insulin-like growth factor $\Pi$ gene disrupted by targeting. Nature $345,78-80$.

Doetschman, T. C., Eistetter, H., Katz, M., Schmidt, W. and Kemler, R. (1985). The in vitro development of blastocyst-derived embryonic stem cell lines: formation of visceral yolk 'sac, blood islands and myocardium. J. Embryol. exp. Morph. 87, 27-45.

Dubois, N. A., Kolpack, L. C., Wang, R., Azizkhan, R. G. and Bautch, V. L. (1991). Isolation and characterization of an established endothelial cell line from transgenic mouse hemangiomas. Exp. Cell Res. 196, 302-313.

Ekblom, P., Sariola, H., Karkinen-Jaaskelainen, M. and Saxen, L. (1982). The origin of the glomerular endothelium. Cell Differ. 11, 35-39.

Folkman, J. and Klagsbrun, M. (1987). Angiogenic factors. Science 235, 442-447.

Freshney, R. I. (1987). Culture of Animal Cells, a Manual of Basic Technique. 2nd ed., (New York: Wiley-Liss, Inc.).

Gonzalez-Crussi, F. (1971). Vasculogenesis in the chick embryo: an ultrastructural study. Am. J. Anat. 130, 441-460.

Gumkowski, F., Kaminska, G., Kaminski, M., Morrissey, L. W. and Auerbach, R. (1987). Heterogeneity of mouse vascular endothelium: in vitro studies of lymphatic, large blood vessel and microvascular endothelial cells. Blood Vessels 24, 11-23.
Haar, J. L. and Ackerman, G. A. (1971). A phase and electron microscopic study of vasculogenesis and erythropoiesis in the yolk sac of the mouse. Anat. Rec. 170, 199-224.

Hooper, M., Hardy, K., Handyside, A., Hunter, S. and Monk, M. (1987). HPRT-deficient (Lesch-Nyhan) mouse embryos derived from germline colonization by cultured cells. Nature 326, 292-295.

Houser, J. W., Ackerman, G. A. and Knouff, R. A. (1961) Vasculogenesis and erythropoiesis in the living yolk sac of the chick embryo. Anat. Rec. 140, 29-43.

Joyner, A. L., Herrup, K., Anerbach, B. A., Davis, C. A. and Rossant, J. (1991). Subtle cerebellar phenotype in mice homozygous for a targeted deletion of the En-2 homeobox. Science 251, $1239-1243$.

Klagsbrun, M. and D'Amore, P. A. (1991). Regulators of angiogenesis. Ann. Rev. Physiol. 53, 217-239.

Koller, B. H., Marrack, P., Kappler, J. W. and Smithies, O. (1990). Normal development of mice deficient in $\beta 2 \mathrm{M}$, MHC class I proteins, and CD8+ T cells. Science 248, 1227-1229.

Lindenbaum, M. H. and Grosveld, F. (1990). An in vitro globin gene switching model based on differentiated embryonic stem cells. Genes Dev. 4, 2075-2085.

McMahon, A. P. and Bradley, A. (1990). The wnt-1 (int-1) protooncogene is required for development of a large region of the mouse brain. Cell 62, 1073-1085.

Miura, Y. and Wilt, F. H. (1969). Tissue interaction and the formation of the first erythroblasts of the chick embryo. Dev. Biol. $19,201-211$

Morris, L., Graham, C. F. and Gordon, S. (1991). Macrophages in haemopoietic and other tissues of the developing mouse detected by the monoclonal antibody F4/80. Development 112, 517-526.

Mortensen, R. M., Zubiaur, M., Neer, E. J. and Siedman, J. G. (1991). Embryonic stem cells lackıng a functional inhibitory Gprotein subunit $\left(\alpha_{12}\right)$ produced by gene targeting of both alleles. Proc. natn. Acad. Sci. U.S.A. 88, 7036-7040.

Mucenski, M. L., McLain, K., Kier, A. B., Swerdlow, S. H., Schreiner, C. M., Miller, T. A., Pietryga, D. W., Scott, W. J. and Potter, S. S. (1991). A functional c-myb gene is required for normal murine fetal hepatic hematopoiesis. Cell 65, 677-689.

Noden, D. M. (1991). Development of cranıofacial blood vessels. In The Development of the Vascular System, (ed. R. N. Feinberg, G. K. Sherer, and R. Auerbach), pp. 1-24. Basel: S. Karger.

O'Brien, B. R. A. (1960). The presence of hemoglobin within the nucleus of the embryonic chick erythroblast. Exp. Cell Res. 21, 226228.

Pardanaud, L., Altman, C., Kitos, P., Dieterlen-Lievre, F. and Buck, C. A. (1987). Vasculogenesis in the early quail blastodise as studied with a monoclonal antibody recognizing endothelial cells. Development 100, 339-349.

Pardanaud, L., Yassine, F. and Dieterlen-Lievre, F. (1989). Relationship between vasculogenesis, angiogenesis, and haemopoiesis during avian ontogeny. Development 105, 473-485.

Peault, B. M., Thlery, J.-P. and Le Douarin, N. M. (1983). Surface marker for hemopoietic and endothelial cell lineages in quail that is defined by a monoclonal antibody. Proc. natn. Acad. Sci. U.S.A. 80, 2976-2980.

Pevny, L., Simon, M. C., Robertson, E., Klein, W. H., Tsai, S. F. D'Agati, V., Orkin, S. H. and Costantini, F. (1991). Erythroid differentiation in chimaeric mice blocked by a targeted mutation in the gene for transcription factor GATA-1. Nature 349, 257-260.

Reagan, F. P. (1915). Vascularization phenomena in fragments of embryonic bodies completely isolated from yolk-sac entoderm. Anat. Rec. 9, 329-341.

Risau, W. and Lemmon, V. (1988), Changes in the vascular extracellular matrix during embryonic vasculogenesis and angiogenesis. Dev. Biol. 125, 441-450.

Risau, W., Sariola, H., Zerwes, H. G., Sasse, J., Ekblom, P., Kemler, R. and Doetschman, T. (1988). Vasculogenesis and angiogenesis in embryonic-stem-cell-derived embryoid bodies. Development 102, 471-478.

Robertson, E. J. (1986). Pluripotential stem cells as a route into the mouse germ line. Trends Genet. 2, 9-13.

Sabin, F. R. (1917). Origin and development of the primitive vessels of the chick and of the pig. Contrib. Embryol. Carnegie Inst. 6, 61124. 
Sabin, F. R. (1920). Studies on the origin of the blood vessels and of red blood corpuscles as seen in the living blastoderm of chick during the second day of incubation. Contrib. Embryol. Carnegie Inst. 9, 215-262.

Schmitt, R. M., Bruyns, E. and Snodgrass, H. R. (1991). Hematopoietic development of embryonic stem cells in vitro: cytokine and receptor gene expression. Genes Dev. 5, 728-740.

Schwartzberg, P. L., Stali, A. M., Hardin, J. D., Bowdish, K. S., Humaran, T., Boast, S., Harbison, M. L., Robertson, E. J. and Goff, S. P. (1991). Mice homozygous for the $a b{ }^{\mathrm{ml}}$ mutation show poor viability and depletion of selected $B$ and $T$ cell populations. Cell 65, 1165-1175.

Soriano, P., Montgomery, C., Geske, R. and Bradkey, A. (1991). Targeted disruption of the c-src proto-oncogene leads to osteopetrosis in mice. Cell 64, 693-702.

Stewart, P. A. and Wiley, M. J. (1981). Developing nervous tissue induces formation of blood-brain barrier characteristics in invading endothelial cells: a study using quail-chick transplantation chimeras. Dev. Biol. 84, 183-192.

Thomas, K. R. and Capecchi, M. R. (1990). Targeted disruption of the murine int-1 proto-oncogene resulting in severe abnormalities in midbrain and cerebellar development. Nature 346, 847-850.

Tybulewicz, V. L. J., Crawford, C. E., Jackson, P. K., Bronson, R. T. and Mulligan, R. C. (1991). Neonatal lethality and lymphopenia in mice with a homozygous disruption of the c-abl proto-oncogene. Cell 65, 1153-1163.

Voyta, J. C., Via, D. P., Butterfield, C. E. and Zetter, B. R. (1984), Identification and isolation of endothelial cells based on their increased uptake of acetylated-low density lipoprotein. J. Cell Biol. 99, 2034-2040.
Wagner, R. C. (1980). Endothelial cell embryology and growth. $A d v$. Microcirc. 9, 45-75.

Wiles, M. V. and Keller, G. (1991). Multiple hematopoietic lineages develop from embryonic stem (ES) cells in culture. Development 111, 259-267.

Williams, R. L., Courtneidge, S. A. and Wagner, E. F. (1988a). Embryonic lethalities and endothelial tumors in chimeric mice expressing polyoma virus middle $\mathrm{T}$ oncogene. Cell 52, 121-131.

Williams, R. L., Hilton, D. J., Pease, S., Wilson, T. A., Stewart, C. L., Gearing, D. P., Wagner, E. F., Metcalf, D., Nicola, N. A. and Gough, N. M. (1988b). Myeloid leukemia inhibitory factor maintains the developmental potential of embryonic stem cells. Nature 336, 684-687.

Wilt, F. H. (1965). Erythropoiesis in the chick embryo: the role of the endoderm. Science 147, 1588-1590.

Yablonka-Reuveni, $\mathbf{Z}$. (1989). The emergence of the endothelial cell lineage in the chick embryo can be detected by uptake of acetylated low density lipoprotein and the presence of a von Willebrand-like factor. Dev. Biol. 132, 230-240.

Zetter, B. R. (1988). Endothelial hetergeneity: influence of vessel size, organ localization, and species specificity on the properties of cultured endothelial cells. In Endothelial Cells, II. (ed. U. S. Ryan), pp. 64-79. Boca Raton: CRC Press.

Zijlstra, M., Bix, M., Simister, N. E., Loring, J. M., Raulet, D. H. and Jaenisch, R. (1990). $\beta 2$-microglobulin deficient mice lack CD4$8+$ cytolytic T cells. Nature $\mathbf{3 4 4}, \mathbf{7 4 2 - 7 4 6}$

(Accepted 31 October 1991) 